\title{
Solar Prosumers in the German Energy Transition: A Multi-Level Perspective Analysis of the German 'Mieterstrom' Model ${ }^{\dagger}$
}

\author{
Raphael Moser*, Chun Xia-Bauer, Johannes Thema (D) and Florin Vondung
}

Energy, Climate and Transport Policy Division, Wuppertal Institute for Climate, Environment and Energy, 42103 Wuppertal, Germany; chun.xia@wupperinst.org (C.X.-B.); johannes.thema@wupperinst.org (J.T.); florin.vondung@wupperinst.org (F.V.)

* Correspondence: raphael.moser@wupperinst.org; Tel.: +49-202-2492-258

+ This paper is an extended version of our paper presented at the 15th Conference on Sustainable Development of Energy, Water and Environment Systems (SDEWES) 2020.

Citation: Moser, R.; Xia-Bauer, C.; Thema, J.; Vondung, F. Solar Prosumers in the German Energy Transition: A Multi-Level Perspective Analysis of the German 'Mieterstrom' Model. Energies 2021, 14, 1188. https://doi.org/10.3390/en14041188

Academic Editors: Tapas Mallick and Poul Alberg Østergaard

Received: 18 December 2020

Accepted: 17 February 2021

Published: 23 February 2021

Publisher's Note: MDPI stays neutral with regard to jurisdictional claims in published maps and institutional affiliations.

Copyright: (c) 2021 by the authors. Licensee MDPI, Basel, Switzerland. This article is an open access article distributed under the terms and conditions of the Creative Commons Attribution (CC BY) license (https:/ / creativecommons.org/licenses/by/ $4.0 /)$.

\begin{abstract}
The expansion of photovoltaics in German cities has so far fallen short of expectations. The concept of 'tenant electricity' ('Mieterstrom' in German), in which tenants of a building are supplied with solar power produced on site, offers great potential here. A study on behalf of the German Federal Ministry for Economic Affairs and Energy estimated the number of tenant households with good conditions for solar tenant electricity at 3.8 million. At the same time, the federal tenant electricity promotion scheme has been in place since 2017 , but only about $1 \%$ of the annual budget has been claimed. The aim of this study is to identify the barriers for and drivers of diffusion of the tenant electricity model. To this end, a qualitative document analysis and a range of semi-structured expert interviews have been conducted. The theoretical framework used to guide the analysis is the multi-level perspective. The main barrier found for tenant electricity diffusion is the legal framework on the regime level, which also leads to high transaction costs of implementing tenant electricity. A social barrier is the inertia of some residents to actively concern themselves with their electricity supply and switch to a tenant electricity contract. Among its drivers are long-term trends such as the increasing electricity demand in urban areas, technical developments like blockchain technology and the increasing deployment of smart meters, and the EU Renewable Energy Directive. As long as the restrictive legal framework prevails, the further diffusion of tenant electricity will remain limited.
\end{abstract}

Keywords: urban energy transition; decentralized electricity generation; multi-level perspective; photovoltaics; Germany

\section{Introduction}

With the mergers at the end of the 1990s, from which the four large utilities RWE, E.ON, EnBW, and Vattenfall emerged, a very profitable decade began for these companies [1,2]. This changed in 2011 with the German government's ambitions for the energy transition, the plan to accelerate the phase-out of nuclear power by 2022 following the Fukushima catastrophe [3] and the global financial crisis [2]. The growth of renewable energies is attributable, among others, to the liberalization of the European electricity market, the targets set by the German government to reduce $\mathrm{CO}_{2}$ emissions [4] and state financial support. Since liberalization in the EU, consumers have been able to choose their electricity supplier freely, and grid access for new electricity suppliers has been legally mandated. The dissolution of old monopolies dominated by fossil fuels led to a market gap for green electricity suppliers.

The still ongoing transition implies a shift in power generation. While formerly generated centrally by large utilities, power is increasingly provided by a mix of centralized and decentralized sources, by large and small utilities, green electricity providers, energy 
cooperatives, private consumers (also called prosumers) and others [5]. In 2019, the production of renewable power in Germany increased by $4.3 \%$ to $42.1 \%$, most of it generated by small- and medium-sized power plants [6].

Within this paper, the transition from centralized to decentralized electricity generation will be analyzed regarding supply and self-consumption of power from photovoltaics. Self-consumption occurs with private home owners but also with landlords and tenants: in the latter case landlords install roof-top photovoltaics and sell the electricity to their tenants (or the model can be contracted out). This concept is called 'tenant electricity' ('Mieterstrom' in German). This business model innovation has the potential to enable the increased on-site supply of renewable electricity, especially in urban areas where this has so far been barely represented [7] and thereby contribute to achieving the climate targets set in the Paris Agreement. A study on behalf of the German Federal Ministry for Economic Affairs and Energy (BMWi) estimated a technical potential for PV tenant electricity of 3,8 million households in apartment buildings amounted to $14 \mathrm{TWh}$ of renewable electricity [8]. For comparison, the annual electricity consumption of 3.8 million households can be estimated at $10.64 \mathrm{TWh}$, based on an average annual electricity consumption of $2800 \mathrm{kWh}$ per household [9]. The total electricity demand of German households is 129 TWh [10]. Bodis et al. estimate the potential of PV systems on German rooftops to 104 TWh per year [11]. This illustrates the major role rooftop PV can play for Germany's future energy supply [11].

Tenant electricity offers numerous advantages for all parties involved: the tenants, the landlords and the potential electricity supplier/contractor. These include the following: the tenant receives renewable PV electricity at a favorable rate [12]. The landlord increases the value of his real estate and obtains additional revenue by leasing the roof area [13]. The utility invests in a sustainable project that enhances their green image and increases customer loyalty [14].

Despite its great technical potential and manifold benefits for stakeholders, development is lagging far behind expectations. In September 2019, the BMWi published an evaluation report on tenant electricity. The report states that only $1 \%$ of the available subsidy budget has been used [15]. The trade press also complained about the weak expansion of tenant electricity: "Poor record after two years of promotion of photovoltaic tenant electricity" [16]. To explain the gap between expectation and reality, the paper aims to investigate the current development of the tenant electricity model in Germany and the barriers and drivers for its diffusion. The analysis provides insights where action by policy makers should be taken in order to promote the upscaling of tenant electricity.

Major contributions to the debate on tenant electricity can be found in the scientific and grey literature mainly after 2015 [8,17-19]. The analysis of major publications on the topic suggests numerous reasons for the sluggish development of tenant electricity: complex metering, complicated accounting procedures, low interest of tenants [20], legal uncertainties regarding the permitted size of a tenant electricity project [21], extensive reporting obligations and limited financial promotion by the government in comparison to the self-consumption of homeowners. This study will complement the existing literature by systematically investigating the barriers for and drivers of diffusion of the tenant electricity model to enable a comprehensive view. It will also provide indications for the assessment of the future development of tenant electricity, especially with regard to long-term trends.

The following two sections describe the legal and theoretical framework and methods applied within the analysis. Subsequently, the results are presented and discussed, structured along the three levels 'niche', 'regime', and 'landscape' based on the theoretical framework. The final section draws conclusions, critically assesses the theoretical framework and provides an outlook for future improvements. 


\section{Legal Framework}

Tenant electricity has already been briefly described in the introduction. In the following, the model is described in more detail regarding the corresponding legal framework and it is then illustrated why, based on the above mentioned characteristics of tenant electricity, the multi-level perspective (MLP) was chosen to guide the analysis of barriers and drivers for its diffusion. Several financial benefits apply to tenant electricity, as levies like the electricity tax and grid levies do not have to be paid and there is a financial tenant electricity promotion by the federal government. However, many rules have to be adhered to by the operators to benefit from the financial advantages [22,23].

- Electricity must not be supplied through the public grid.

- The tenant electricity tariff must be at least $10 \%$ cheaper than the local basic supply tariff.

- Tenants have the choice of receiving electricity directly from the roof or from a utility company. The tenant may not be bound by the tenant electricity contract for longer than one year and may terminate it independently of the tenancy agreement.

- The maximum output of the PV system may not exceed $100 \mathrm{kWp}$ per building.

- The PV system must be newly installed on the building to be supplied or in the neighborhood [24].

Jäger-Waldau et al. state that Germany is in the middle of the field internationally as far as tax, levy and subsidy regimes, connection charges and permit fees are concerned, with better conditions in Switzerland and Greece and worse in countries such as the USA, Italy, and Spain [23,25]. Legally and practically, the promotion is limited to photovoltaics as a renewable generation source. In the medium to long-term, urban wind energy is also conceivable [26] in conjunction with the tenant electricity model.

\section{Methods and Theoretical Framework}

The above-mentioned rules established at political level have a significant impact on the economic viability of the model. The success of tenant electricity not only depends on factors such as administrative costs or subsidies and legal requirements. Technical and social factors are also relevant. The legally required measurement systems are complex and have to be adapted for each project. Many tenants are hardly interested in their electricity supply and have to be convinced with great effort to participate [19].

In addition, various governance levels are involved: most of the relevant legal framework conditions are defined at the federal level, but tenant electricity projects are implemented locally and in part initiated by municipalities via the local municipal utilities. In addition, the federal states also play a role, e.g., by setting up subsidy programs for tenant electricity [27], and the European Union, via its Renewable Energy Directive, requires Member States to facilitate renewable energy communities, which could be constituted by tenant electricity projects [28]. MLP was chosen because it can integrate the economic, political, technical and social factors and local, state, federal and European levels, thus allowing a comprehensive analysis of the diffusion environment.

MLP offers a research heuristic for analyzing the development process of a niche innovation [29] such as tenant electricity is currently undergoing. To date, the topic of tenant electricity has not been comprehensively examined using a theoretical framework such as the multi-level perspective.

Geels et al. state that "[ ... ] the dominant analytical perspectives, grounded in neoclassical economics and social psychology, focus upon marginal changes and provide only limited guidance on how such transformations may occur and how they can be shaped" [30]. MLP promises better guidance than the dominant analytical perspectives by analyzing three levels. First, the socio-technical landscape, which contains large trends like globalization or developments like climate change that cannot be influenced by single actors. The landscape level can pressure or stabilize the second level, the regime. This level includes institutions, socio-economic and legal structures and (incumbent) actor constellations. It is the level, where economic, political and social factors, routines, and institutions play a core role and where the dominant economic and governmental actors are 
located. The third is the niche level, which is the environment in which radical innovations can emerge and grow, and which initially is outside public awareness. This is where technical innovations and new business models are developed. Four proxies conceived by Geels and Schot can be used to determine the stage of development of innovations [31]. If all four characteristics are met, the innovation can be considered as market-ready and prepared for the breaking into the mainstream market.

- Proxy 1-Stabilized learning processes: Stabilized learning processes concern the question of whether major development leaps can still be expected for innovations or whether a path of incremental improvement is to be assumed and most problems have been solved [31].

- Proxy 2-Support network: In order to help an innovation achieve a breakthrough, not only dynamic initiators are needed. Also necessary are other actors, such as associations that support the cause politically and demand better framework conditions, or neighboring industries that also have an influence on the diffusion of the innovation and mutual learning [29].

- Proxy 3-Improvements and expectations: With this proxy, Geels and Schot had rather technical or economic parameters of a product in view, e.g., an improved price-performance ratio or the expectation of further improvements [31].

- Proxy 4-Market share: Geels and Schot view innovations with more than five per cent market share in market niches as viable for a wider break through [31]. The value of five per cent derives from the diffusion literature, which regards innovations with a market share between five and twenty per cent as established [32]. It typically refers to diffusion of technologies rather than innovative business models. The applicability is therefore limited in the case of tenant electricity.

To identify relevant barriers and drivers and to provide a preliminary assessment regarding their relevance to explain the observed low diffusion a document analysis was conducted. Subsequently, the results were reviewed and complemented with interviews with selected experts on the matter.

The procedure of the document analysis summarized in Table 1 followed the specifications of qualitative content analysis according to Mayring [33], leaving aside a detailed analysis of the context of origin. This proceeding was chosen to efficiently process the large number of documents.

Table 1. Document analysis.

\begin{tabular}{ll}
\hline & \multicolumn{1}{c}{ Document Analysis } \\
\hline & $\begin{array}{l}\text { Guidelines and information brochures with a focus on tenant electricity in practice [13,18], studies on } \\
\text { tenant electricity with empirical surveys and potential analyses [8,19,34-36], evaluation reports on the } \\
\text { development of tenant electricity to date [15,37], association statements on demanded improvements of } \\
\text { tenant electricity [38,39], articles from specialist magazines [40-43], newspaper articles [21,44], expert } \\
\text { presentations [14,45,46]. }\end{array}$ \\
\hline \multirow{2}{*}{ Focus of the analysis } & $\begin{array}{l}\text { Existing barriers and drivers as well as background information and assessments of } \\
\text { foreseeable developments. }\end{array}$ \\
\hline
\end{tabular}

The chosen interview approach summarized in Table 2 is guideline-based and includes elements of both episodic and problem-centered interviews [47-49]. 
Table 2. Expert interviews.

\begin{tabular}{cl}
\hline & \multicolumn{1}{c}{ Expert Interviews } \\
\hline Interviewed experts & Scientist, consultant, lawyer, representative of an association and a government organization \\
\hline Focus of the analysis & $\begin{array}{l}\text { Background, processes and facts of tenant electricity projects /models as well as motives for action and } \\
\text { assessments of developments }\end{array}$ \\
\hline When & October and November 2019 \\
\hline Documentation & $\begin{array}{l}\text { The notes recorded during the interviews were then written into a protocol of results. Significant } \\
\text { quotations were written down in detail. }\end{array}$ \\
\hline Evaluation & $\begin{array}{l}\text { The protocols of results were evaluated with regard to particularly relevant or previously unknown } \\
\text { information and a summary was produced. Based on the findings of the interviews, previous research } \\
\text { results were validated, extended or modified. }\end{array}$ \\
\hline
\end{tabular}

\section{Results and Discussion}

After giving a general overview with the following graphic, the results of the analysis are presented and discussed in more detail structured according to the three levels of the MLP.

Figure 1 shows developments on all three levels, with the landscape level influencing the two lower levels and regime and niche influencing each other [50,51]. Developments at the landscape level such as climate change or the energy transition exert pressure for change on the regime, which is still characterized by centralized power generation based largely on fossil fuels. At the same time, the landscape level also affects the actors in the niche, for example by stimulating the use of renewable energies. The current status of tenant electricity innovation can be considered relatively far to the left on the timeline, as the influence of tenant electricity on the regime is still limited. One of the reasons for this is that the regime has a relatively strong influence on the niche through the regulatory framework. The pressure of the landscape level on the dominant regime can lead to a window of opportunity in which the more agile and adaptable niche actors gain market share (or innovative regime actors take a partial niche position) [52] and can ultimately replace the current regime actors. Thus, a transition would occur from a centralized, fossil-based power supply system to a decentralized, renewable power supply system.
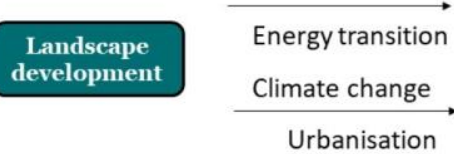



Blockchain

$$
\begin{aligned}
& \underset{\text { Smart meter }}{\text { rollout }} \\
& \underset{\text { Fridays for Future }}{\longrightarrow}
\end{aligned}
$$

\section{Landscape}

development

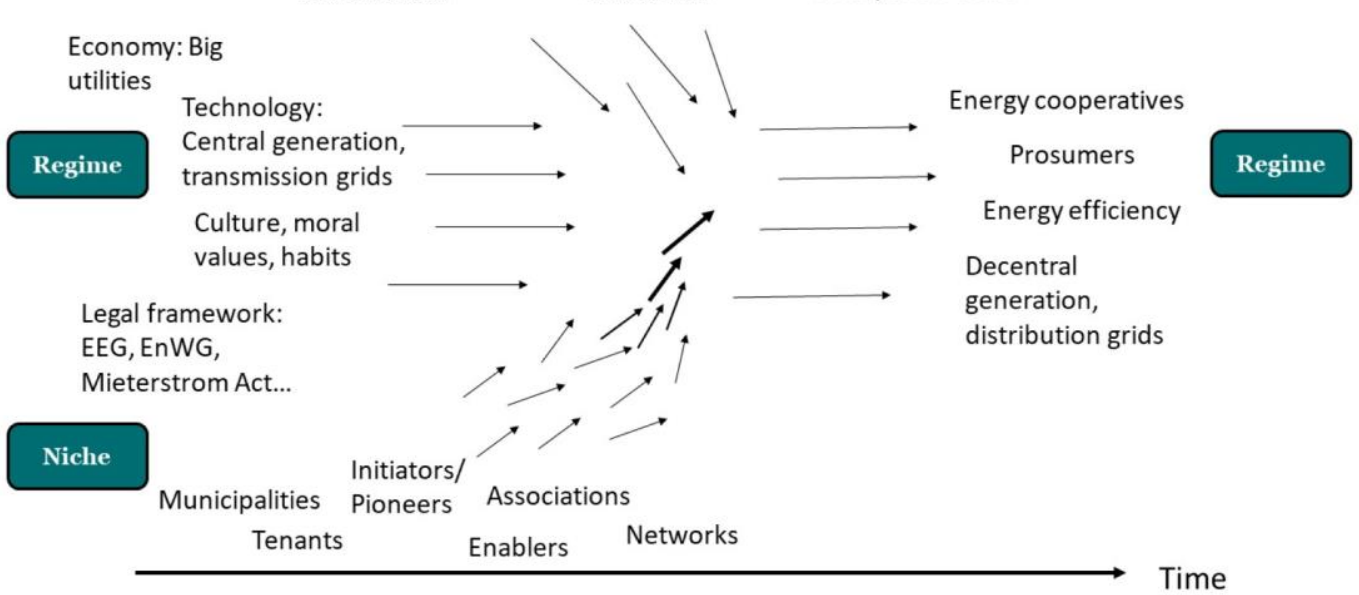

Figure 1. Transition of the energy system with tenant electricity; the length of the arrows refers to the time, the width to the intensity of the influence exerted; Source: Own illustration, based on [50]. 


\subsection{Niche: Development of Tenant Electricity}

At the end of the 1990s, the Berliner Energieagentur was one of the first niche actors to implement the tenant electricity model [53]. Since then there have been many developments in technology and administrative processes and also changes to the legal framework including financial support, which will be discussed below in the section on regime.

\subsubsection{Proxy 1: Stabilized Learning Processes}

When asked about possible improvements for tenant electricity models, it was stated in the interviews that the potential for creativity had been exhausted under the current conditions. Digital processes for billing and managing customer contact more efficiently were developed. After various metering concepts were tested, the most effective one was found as mentioned in the BMWi tenant electricity report from 2019 [15]. The report asked operators about the metering concept used, "the result of the survey shows that the Summenzählermodell without or with smart meter is the most frequently used and cost-efficient meter concept for EEG-supported tenant electricity projects. [Its] viability has been demonstrated in this respect" [15].

Various business models have been developed and tested. Specialized ESCOs and energy suppliers have developed and acquired all necessary competencies to implement tenant electricity models, while others, such as municipal utilities, rely on external consulting to cover all processes for their tenant electricity offers.

The dissemination of smart meters and the development of blockchain technology are likely to become more relevant in the future with regard to the technical side and the administrative costs of tenant electricity models. Smart meters are advantageous because they allow more flexible electricity tariffs and potentially avoid the need for technical retrofitting. Blockchain allows energy deliveries to be billed more efficiently, as no intermediaries between the supplier and tenant are necessary [54]. This independence serves to strengthen the role of prosumers by making it easier and more profitable to market small quantities of electricity and it facilitates the coordination of tenant electricity models [35].

A mixed picture emerges in the field of standardization in the area of tenant electricity models. On the one hand, there are currently difficulties with standardization with regard to processes and actor constellations, since it is still a project business that has special requirements on a case-by-case basis and various actors that have to cooperate. On the other hand, in several expert interviews by Flieger et al. [35] it was stated that, in the medium term, cost savings can be expected through standardization with regard to business models, service offers and technological solutions.

\subsubsection{Proxy 2: Support Network}

Numerous associations can be identified that support the concept [39]. Many of them have participated in the process of formulating the Tenant Electricity Act by submitting statements to the BMWi [55]. The associations represent diverse relevant industries and groups, representing end-use customers and tenants, energy suppliers, and landlord associations.

Geels and Schot view the discussed proxy as true if "powerful actors have joined the support network" [29]. The power of an association is hard to measure empirically, but economic size is correlated with political weight, since, for example, many jobs are created by the respective industry. BSW for example represents 800 companies in the solar industry [56] and the BNE is a comprehensive association of the renewable energy industry, which has an increasing number of members [57]. Additionally, there is the residential housing industry with the $\mathrm{VdW}$ association representing 475 members, which together manage 1.1 million apartments [58].

Overall, the support network has a reasonably powerful basis and has supporters from a wide variety of industries who agree on the broad goal of demanding better conditions for tenant electricity. However, it can be assumed that tenant electricity does not have 
the highest priority in lobbying for change [59]. In addition, there is disagreement over details. For example, Haus and Grund (building owner association) demands that tenants be required to purchase tenant electricity from landlords, which the Verbraucherzentrale (consumer protection association) rejects.

\subsubsection{Proxy 3: Improvements and Expectations}

From a technical point of view, tenant electricity is relatively advanced; "there is little room for creativity left," according to one interview partner. As will be shown in the following section, the legal framework is the predominant barrier to greater sales potential. A greater sales volume would enable economies of scale and thus increase the economic performance of tenant electricity models.

\subsubsection{Proxy 4: Market Share}

According to a study commissioned by the BMWi, the potential for a substantial market share exists [15]. However, the current market share of tenant electricity has so far been negligible. The BMWi report states that only $1 \%$ of the available subsidies have been used [15]. In 2020, the total installed generation capacity for subsidized tenant electricity was 22.3 MWp [60], while total PV generation was over 53 GWp [61]. Thus, tenant electricity accounted for 0.04 per cent of German PV generation capacity. This picture is corroborated when looking at the subsidies for PV. In 2017 and 2018, the feed-in expenses for tenant electricity were less than 200,000 EUR, while the total feed-in payments for PV amounted to almost 10 billion EUR [15]. Accordingly, tenant electricity is still very far from a significant market share.

\subsection{Regime}

At the regime level, legal barriers predominate. The role of the Federal Network Agency (BNetzA) is given special consideration. The BNetzA "was established in 1998 [ ... ]. It is a separate higher federal authority within the scope of business of the Federal Ministry of Economics and Technology [ ... ], which holds formal supervisory rights" [62]. In the energy sector, the Federal Network Agency is responsible for ensuring a secure, low-cost, consumer-friendly, efficient and environmentally friendly grid-bound supply of electricity and gas to the general public [63]. In recent years, the need for a low-cost electricity supply has been repeatedly emphasized by politicians and the media [64,65], after the German electricity price had risen relatively sharply to one of the highest in Europe, partly due to the EEG levy [66,67]. Lauber and Jacobsson [68] criticize this increasingly dominant narrative, which is similarly described by Dehler-Holland et al. and Schweiger et al. [69,70]. By decision of the then liberal-conservative coalition, energy-intensive companies have been partially exempted from paying the EEG levy on their electricity consumption since 2012 [71], which increases the levy to be paid for all other consumers accordingly. "Despite using $25 \%$ of Germany's electricity, these exempt companies pay only $2 \%$ of the overall cost of the FIT levy" [72]. This and other reasons led to a legal dispute between the EU and Germany [73-75].

During the expert interviews a clear picture emerged that the legal framework was the main barrier to tenant electricity diffusion as it drives the economic viability. In this context, reference was repeatedly made to the BNetzA, which generally reacts defensively or even in a hostile manner to tenant electricity and prosumer models in general. It turned out that this assessment is widespread among experts. However, the position of the BNetzA has not yet been discussed in detail in the literature. The EU Renewable Energy Directive which is discussed subsequently favors the diffusion of tenant electricity.

\subsubsection{The Main Barrier: The Legal Framework for Tenant Electricity}

There is a complex framework of laws, regulations and standards, which must be met by tenant electricity projects, especially if they want to benefit from financial promotion. The regulations cover the duties of a tenant electricity supplier, customer base, size of PV 
systems, electricity measuring and billing, taxes and levies, and support schemes. There is a large number of relevant laws and directives as well as ongoing legal disputes. The more relevant laws and directives include the following:

- The Renewable Energy Act (EEG) has a strong influence on the economic efficiency of tenant electricity through feed-in tariffs and the EEG levy to be paid. The EEG levy amounts to 6.5 cent per kWh in 2021 [76]. Decreasing feed-in tariffs increase the need for high electricity sales in the building as the margin is higher compared to electricity fed into the grid. Under the EEG, delivering tenant electricity to an end consumer makes the supplier an electricity supply company, which comes with several duties and reporting requirements - a required effort that is virtually impossible for small housing companies or private landlords to manage [13]. The amendment of the Renewable Energy Act came into force at the beginning of 2021 and could, therefore, only be taken into account to a limited extent. It brought some improvements for tenant electricity, for example increased financial support and corroboration of claims to the tenant electricity subsidy in case of contracting [77]. However, many bureaucratic barriers remain [78].

- $\quad$ The Energy Industry Act (EnWG) lays down many of the bureaucratic obligations for tenant electricity providers, which cause expenses and thus make the business model less profitable [8].

- The Tenant Electricity Act introduced the financial promotion of tenant electricity in June 2017. The amount of subsidy paid per kWh depends on the size of the PV system and had decreased in recent years with the above-mentioned 2021 EEG amendment bringing an increase (Handelsblatt\#). The design of the act is controversial, mainly due to the worse framework conditions compared to own consumption by private home owners. It brought improvements to the tenant electricity model but not to the extent that many associations, for example, would have preferred [39].

- The electricity tax defined in the Electricity Tax Act (StromStG), can be avoided by suppliers under certain conditions. This is helpful for the tenant electricity model, but applying for a tax exemption also requires effort [8].

- The introduction of the Energy Collection Act (EnSaG) represented a hard cut for the tenant electricity promotion, as it reduced the subsidy rate per $\mathrm{kWh}$ for larger tenant electricity models [79].

- The numerous grid levies increase the attractiveness of tenant electricity compared to electricity from the public grid, as levies have not to be paid. Due to the local variation of grid levies, the attractiveness of tenant electricity varies considerably between regions $[14,18]$.

- $\quad$ The Trade Tax Act (GewStG) plays a special role for providers of tenant electricity from the residential building industry, since residential building companies run the risk of losing their tax privileges by becoming active in power supply [8]. A change in the law at the beginning of 2021 brought more reliability here, although certain uncertainties still remain [80].

- The Energy Saving Directive (EnEV) contains at least a small incentive for tenant electricity by defining a limit value for energy consumption that new residential and office buildings must not exceed. Renewable electricity can be deducted from this energy consumption if it is generated locally and consumed at least in part, as is the case with tenant electricity models [8].

- Several ongoing legal disputes about the permissible number of residential units that may belong to a tenant power system lead to a lack of investment security [21].

- The EU Renewable Energy Directive explicitly requires that legal barriers in Member States must be removed in order to enable models such as tenant electricity [28].

In summary, the legal framework predominantly creates significant barriers to tenant electricity. In order to put all the laws and regulations into perspective, the five interviewed experts were asked which goals they believe determine the federal government's handling of tenant electricity. They expressed in the interviews that the Federal Government has 
moderate interest in decentralized, local energy production. It rather favors large power lines, offshore wind farms and similar, and is in direct exchange with the large suppliers.

\subsubsection{Tenant Electricity in a Centralized Energy System}

The BNetzA was named in the interviews to be a key player in blocking tenant electricity diffusion. The basic problem is addressed by Köhler et al., who in their MLP analysis of transition in the energy, housing and water sector come to an astonishingly accurate diagnosis for the case of tenant electricity, even though the assessment is of general nature: "In the energy sector, for example, the established energy suppliers had a very strong position for a long time and still have a great influence on politics. However, their influence has declined significantly, while the new market players (especially in the field of renewable energies) have gained importance. [ . . ] the actual problem would have to be dealt with at a completely different level of abstraction, for example: the energy market is organized for centralized electricity production and supply, while renewable energy producers need a decentralized market structure" [50]. At this point the clash between decentralized renewable energy generation and central conventional energy generation or between the niche and the regime level becomes evident.

Quotable statements such as the following from a lawyer specializing in tenant electricity are exceptional in the research on the role of the BNetzA in relation to tenant electricity: "The BNetzA ultimately torpedoes an innovative business model, positions itself against decentralized energy supply with renewable energies and combined heat and power generation and against competition between municipal and civic actors and large cross-national corporations" [81]. The context here is a tenant electricity project that was rejected by the agency because "the energy system with 143 residential units was too large to still be able to fulfil the criterion of lacking significance for competition" [21]. The legal dispute will not be addressed in detail, but the underlying phenomenon is of interest. The BNetzA interprets the legal situation restrictively and thus blocks the potential of tenant electricity. Here, the power of the agency becomes apparent-it cannot pass any laws, but it can interpret the existing laws with a certain tendency.

In an interview, BNetzA representative Peter Stratmann argues that there is a strong focus by the agency on keeping the overall electricity price low: "The very careful calculation of the Federal Ministry of Economics has shown that 3.5 cents per Kilowatt hour are needed for a tenant electricity model. [ ... ] We should make sure that it is cheap for everyone and not for the individual." [82]. The underlying logic is that, thanks to tenant electricity (and homeowner self-consumption), while more and more electricity customers do not have to pay grid charges for their electricity consumption, the burden of grid charges needs to be carried by a smaller group of end consumers, leading to higher grid levies for them.

With regard to the numerous obligations tenant electricity providers have to fulfil as electricity suppliers, their co-responsibility for security of supply is mentioned; "Consequently regulation must be strict on the basics" [83]. The BNetzA implements this requirement by insisting on "fulfilment of all market obligations by all actors (data, responsibility, forecasts, timetables, etc.)" [83].

This strict or even blocking attitude was addressed in almost all expert interviews. Reference was made to the attached topic of electricity self-consumption. The fact that the guidelines on electricity self-consumption published by the BNetzA comprise 135 pages is considered a sign that self-consumption is intentionally complicated.

According to one interviewee, the mindset of the federal government is "we want to switch to renewable energies but besides that everything should stay the way it is". This can only happen if there is a clear separation between consumers and producers. Prosumers are a nuisance in this picture. The interviewee stated that this is the prevailing dogma in the Federal Government, BMWi and BNetzA and as long as it prevails, the trajectory of tenant electricity is relatively hopeless, because decentralized self-consumption is explicitly not desired. 
Another interviewee added that a centralized system is easier to control. In addition, the BNetzA is occupied with other problems. German industry in international competition wants low electricity prices, in other words the lowest possible taxes and levies on electricity. By comparison, tenant electricity or prosumer concerns in general are 'peanuts' and are heading in the wrong direction, as they reduce the number of electricity customers who contribute to the payment of the levies.

Overall, this shows that there is agreement among the interviewed experts that a stronger diffusion of tenant electricity is currently not desired at the federal level. Prosumers do not fit into the envisioned future energy system, which is easier to control and manage with fewer electricity suppliers. In addition, the aim is for as many electricity consumers as possible to pay levies in order to keep them low for the average consumers.

The interviewed experts agreed that the current political conditions are unlikely to lead to any significant improvement in the legal framework in the near future. In the following quote, structural reasons for this sluggish development are identified: "Walz and Köhler [ ... ] put forward the thesis that grid-bound infrastructures such as electricity or water are more likely to be disruptive because of the strong position of existing actors due to monopolistic bottlenecks, while the transformation process in improving efficiency in energy and material flows is more likely to follow a continuous process of change. Rogge et al. [ ... ] argue that regulation of the electricity grid increases the regime's persistence, but could also enable faster change if the political will is given" [50].

In the highly regulated electricity market, innovations are strongly dependent on leeway provided by the legal framework, which is very narrow in the case of tenant electricity. A change of political will could however trigger rapid, disruptive change. In the case of tenant electricity, this would be legal improvements at the federal level. For a comprehensive and viable solution the establishment of a legally and organizationally newly designed energy system would be necessary.

\subsubsection{EU Renewable Energy Directive}

The so-called winter package of the EU plays an important role for the future legal framework of tenant electricity. It contains the "Directive (EU) 2018/2001 [...] on the promotion of the use of energy from renewable sources" [28]. Among other things, it deals with decentralized energy generation and community self-supply. The directive was analyzed by Lenz [84] with regard to tenant electricity, on the basis of which the following quotations from the directive are selected.

Article 21 ('Self-supplier in the renewable electricity sector') of the Directive clarifies why the Directive applies specifically to the tenant electricity problem with the hindering legal framework: "Member States shall ensure that renewables self-consumers, individually or through aggregators, are entitled [ ... ] to generate renewable energy, including for their own consumption, [ ... ] without being subject [ ... ] in relation to their self-generated electricity from renewable sources remaining within their premises, to discriminatory or disproportionate procedures, and to any charges or fees" [28]. It explicitly emphasizes that all end consumers should have access to self-consumption "including those in low-income or vulnerable households" and that Member States should "address other unjustified regulatory barriers to renewables self-consumption, including for tenants" [28]. Member States shall create favorable conditions for the development of renewable energy communities by ensuring that "unjustified regulatory and administrative barriers to renewable energy communities are removed; [ ... ] the relevant distribution system operator cooperates with renewable energy communities to facilitate energy transfers within renewable energy communities; [ . . . and] the participation in the renewable energy communities is accessible to all consumers, including those in low-income or vulnerable households" [28].

All in all, the references seem to be tailored to the topic of tenant electricity in the German context, in which legal and administrative barriers are considerable and should be removed according to the Directive. However, according to Lenz [84], the German government may only adopt certain passages of the Directive such like the following to 
make only minor changes to the legal framework for tenant electricity: "However, in order to prevent that incentive from affecting the financial stability of support schemes for renewable energy, that incentive could be limited to small installations with an electrical capacity of $30 \mathrm{~kW}$ or less" [28].

\subsection{Landscape}

\subsubsection{Perception of Climate Change and Green Electricity Consumption}

The increased attention to climate change in general and the greater demand for green electricity in particular can be assumed to create favorable framework conditions for decentralized renewable energy generation, including tenant electricity. On the one hand, climate change questions the current form of predominantly fossil-based energy generation, thereby pressuring the current regime, and on the other hand, tenant electricity offers an alternative for the resulting supply gap. However, inertia, lack of information, or cognitive dissonance can limit the effect, as the relatively small proportion of consumers purchasing green electricity shows. This inertia has been observed in surveys $[85,86]$ and confirmed in the expert interviews conducted.

\subsubsection{Urbanization and Rising Electricity Consumption}

From 2000 to 2017, urbanization (i.e., the share of the population living in an urban environment) in Germany had increased steadily from 75 per cent to at least 77 per cent [87]. In Germany, an increased demand for residential space is expected, predominantly in cities, of about 230,000 apartments per year until 2030 [88]. A large proportion of the apartments required are likely to be built in multi-storey apartment buildings, thus increasing the potential for tenant electricity, especially in view of the fact that it is much easier to implement tenant electricity in new construction [18].

Growing cities have a growing demand for electricity [89]. Tenant electricity can make a contribution here and thus also reduce the need for grid expansion, which will be necessary to supply cities with more electricity from far-off power plants. A much stronger driver of growing electricity consumption in cities is the trend towards sector coupling. This includes electrical heat supply, for example with heat pumps, and e-mobility, which is strongly fostered by the federal government by promoting the purchase of electric cars [90]. Charging stations at home and heating with electricity will result in a much higher demand for electricity. In addition, there are increasing storage losses and growing power demand for process heat [91]. There have even been warnings of a blackout due to the additional power requirement of electric cars [92].

\section{Conclusions}

Regarding the niche level, this study has shown that the technical and administrative learning phase for the tenant electricity model has largely been completed, a broad support network exists, the market potential is high, but market penetration is negligible. The administrative processes and necessary technical concepts have been developed and tested by pioneers and have proven to be functional. Expert interviews yielded that the technical and administrative development potential of tenant electricity is largely exhausted.

Examination of the regime level showed that the federal regulatory framework and institutional actors remain a major barrier for scaling up tenant electricity. Based on the conducted expert interviews, the Federal Network Agency has been identified as a key player that enforces compliance with the laws. Its interest lies in a clear separation between electricity producers and consumers, a large number of contributors to whom network charges are distributed and a manageable number of electricity suppliers. Thus, it blocks the potential of tenant electricity, especially by interpreting the current legal situation restrictively.

The consideration of long-term trends at the landscape level has illustrated that most of the foreseeable developments and trends are likely to have a positive effect on tenant electricity. The perception of climate change, the rising electricity consumption in cities due 
to sector coupling and urbanization, and the increasing importance of climate protection all point to improving conditions and increasing demand for tenant electricity in the future. In the long term, the expansion of rooftop PV generation in urban areas is likely to increase strongly. MLP has proven helpful in structuring the complex interrelationships of the tenant electricity model and highlighting interactions between the three levels.

As far as drivers and barriers are concerned, the largest obstacle remains the legal framework for tenant electricity or in other words the lack of political will to reform it. Among the political drivers are the EU Renewable Energy Directive, the existing political support network for tenant electricity, promotional programs and regulations in the EnEV.

When looking at economic barriers, the cost-effectiveness of tenant electricity models is strongly linked to the regulatory framework, currently causing high administrative and technical costs. A mixed picture emerges in the field of standardization in the area of tenant electricity models with divided expert opinions on this topic.

Economic drivers are the competitive advantages of tenant electricity for building owners and utilities/contractors to attract new customers and rising electricity consumption in cities. Additionally, the residential industry generates competitive pressure on the energy suppliers by offering tenant electricity models themselves.

A social driver is the generally positive public account of green electricity. At the same time, the population is predominantly inert when it comes to changing electricity providers and there is a lack of interest in tenant electricity and electricity supply in general. The technical drivers show how interactions of different niches can accelerate their scaling up. They include the diffusion of smart meters, potentially allowing more flexible electricity tariffs and less need for technical retrofitting, and the potential of blockchain technology, allowing energy deliveries to be billed more efficiently.

In the strongly regulated electricity market, innovation and disruptive change are highly dependent on the legal framework. A new regulation of the electricity market with more favorable conditions for tenant electricity is not in sight in the short term. In some of the interviews, it became clear that a comprehensive restructuring of the energy system is necessary in order to align it to decentralized supply concepts such as tenant electricity. In this context, future research can examine which concepts for new electricity market designs have already been developed, how tenant electricity would fit in and which advocates and chance for successful implementation such concepts would have.

The scientific debate about tenant electricity is still at its beginning. Thus, only a limited number of scientific sources are available. More abstract analyses of the topic as well as empirical research regarding economic viability of individual projects and a full picture of all existing projects, including those who do not claim state financial support, would be necessary to conduct analyses on a more comprehensive database. Another field for potential future study would be the thorough assessment of different tenant electricity business models. The amendment to the Renewable Energy Act at the beginning of 2021 has improved the conditions for tenant electricity at the neighborhood level, which enables new business models for tenant electricity projects across buildings.

Author Contributions: Conceptualization: R.M., C.X.-B., F.V. and J.T.; investigation: R.M.; methodology, R.M., C.X.-B., F.V. and J.T.; supervision: C.X.-B.; validation: R.M.; visualization: R.M. All authors discussed the results and contributed to the final manuscript. All authors have read and agreed to the published version of the manuscript.

Funding: This article was written as part of the research project "Exploring and Assessing Sustainable Transition in Chinese and German Urban Areas (EAST)" funded by the German Research Foundation (DFG), grant number 391956384. The APC was funded by Wuppertal Institute.

Conflicts of Interest: The authors declare no conflict of interest. 


\section{References}

1. Wagner, O.; Adisorn, T.; Tholen, L.; Kiyar, D. Surviving the Energy Transition: Development of a Proposal for Evaluating Sustainable Business Models for Incumbents in Germany's Electricity Market. Energies 2020, 13, 730. [CrossRef]

2. Geels, F.W.; Kern, F.; Fuchs, G.; Hinderer, N.; Kungl, G.; Mylan, J.; Neukirch, M.; Wassermann, S. The enactment of socio-technical transition pathways: A reformulated typology and a comparative multi-level analysis of the German and UK low-carbon electricity transitions (1990-2014). Res. Policy 2016, 45, 896-913. [CrossRef]

3. Upham, P.; Eberhardt, L.; Klapper, R.G. Rethinking the meaning of "landscape shocks" in energy transitions: German social representations of the Fukushima nuclear accident. Energy Res. Soc. Sci. 2020, 69, 101710. [CrossRef]

4. Agentur für Erneuerbare Energien. Liberalisierung des Strommarktes: Befreiung für neue Anbieter und die Erneuerbaren. Available online: https:/ / www.unendlich-viel-energie.de/liberalisierung-des-strommarktes-befreiung-fuer-neue-anbieter-unddie-erneuerbaren (accessed on 5 November 2020).

5. Rechsteiner, R. German energy transition (Energiewende) and what politicians can learn for environmental and climate policy. Clean Technol. Environ. Policy 2020, 1-38. [CrossRef]

6. Umweltbundesamt. Erneuerbare Energien in Zahlen. 2020. Available online: https://www.umweltbundesamt.de/themen/ klima-energie/erneuerbare-energien/erneuerbare-energien-in-zahlen\#statusquo (accessed on 26 February 2020).

7. KfW. KfW-Energiewendebarometer. 2020. Available online: https:/ /www.kfw.de/PDF/Download-Center/Konzernthemen/ Research/PDF-Dokumente-KfW-Energiewendebarometer/KfW-Energiewendebarometer-2020.pdf (accessed on 14 January 2021)

8. Ministry for Economic Affairs and Energy. Schlussbericht Mieterstrom-Rechtliche Einordnung, Organisationsformen, Potenziale und Wirtschaftlichkeit von Mieterstrommodellen (MSM). Available online: https://www.bmwi.de/Redaktion/DE/ Publikationen/Studien/schlussbericht-mieterstrom.pdf?_blob=publicationFile\&v=10 (accessed on 17 January 2020).

9. Statista. Jährlicher Stromverbrauch eines privaten Haushaltes in Deutschland. Available online: https://de.statista.com/statistik/ daten/studie/245790/umfrage/stromverbrauch-eines-privathaushalts-in-deutschland/ (accessed on 14 January 2021).

10. German Environment Agency (UBA). Entwicklung des Stromverbrauchs nach Sektoren. Available online: https://www. umweltbundesamt.de/daten/energie/stromverbrauch (accessed on 14 January 2021).

11. Bódis, K.; Kougias, I.; Jäger-Waldau, A.; Taylor, N.; Szabó, S. A high-resolution geospatial assessment of the rooftop solar photovoltaic potential in the European Union. Renew. Sustain. Energy Rev. 2019, 114, 109309. [CrossRef]

12. Ministry for Economic Affairs and Energy. Mieterstrom: Energiewende im Eigenen Haus. Available online: https://www.bmwi. de/Redaktion/DE/Artikel/Energie/mieterstrom.html (accessed on 15 September 2020).

13. Bundesverband Solarwirtschaft. Geschäftsmodelle mit PV-Mieterstrom. Available online: https://www.pv-mieterstrom.de/wpcontent/uploads/2016/11/PV_Financing_Mieterstrom.pdf (accessed on 18 January 2020).

14. Schnelte, A. Einführender Vortrag in das Thema Mieterstrom. Available online: http://www.icrollout.de/wp-content/uploads/ 2017/05/2.-Netzwerkveranstaltung_Vortrag-PwC_Schnellte-T\%C3\%B6llner-Kremer.pdf (accessed on 9 February 2020).

15. Ministry for Economic Affairs and Energy. Mieterstrombericht nach § 99 Erneuerbare-Energien-Gesetz 2017. Available online: https:/ / www.erneuerbare-energien.de/EE/Redaktion/DE/Downloads/Berichte/mieterstrombericht-eeg-2017.pdf (accessed on 19 January 2020).

16. Enkhardt, S. Dürftige Bilanz nach zwei Jahren Förderung von Photovoltaik-Mieterstrom. Available online: https://www. pv-magazine.de/2019/07/25/duerftige-bilanz-nach-zwei-jahren-foerderung-von-photovoltaik-mieterstrom/ (accessed on 4 February 2020).

17. Behr, I.; Großklos, M. Mieterstromein Beitrag zur Energiewende. In Praxishandbuch Mieterstrom, 1st ed.; Springer Vieweg: Wiesbaden, Germany, 2017; pp. 3-14. [CrossRef]

18. Verband kommunaler Unternehmen. Vom Mieterstrom zur Quartiersversorgung-Energiekonzepte vor Ort umsetzen. Available online: https://www.vku.de/fileadmin/user_upload/Verbandsseite/Themen/Energiewende/180620_Broschuere_ Mieterstrom_final.pdf (accessed on 19 January 2020).

19. Schäfer, M. Akzeptanzstudie 'Mieterstrom aus Mietersicht'—Eine Untersuchung verschiedener Mieterstromprojekte in NRW; Wuppertaler Studienarbeiten zur nachhaltigen Entwicklung, Wuppertal Institut: Wuppertal, Germany, 2019.

20. Koch, J.; Christ, O. Household participation in an urban photovoltaic project in Switzerland: Exploration of triggers and barriers. Sustain. Cities Soc. 2018, 37, 420-426. [CrossRef]

21. Wraneschitz, H. Mieterstrom bald Chancenlos? Bundesnetzagentur mit Rigorosen Entscheidungen. Available online: https://www.bayerische-staatszeitung.de/staatszeitung/wirtschaft/detailansicht-wirtschaft/artikel/mieterstrom-baldchancenlos.html\#topPosition (accessed on 17 February 2020).

22. Energie Agentur. NRW. Mieterstrom kurz erklärt-Neue Perspektiven für Vermieter und Mieter. Available online: https: / / broschueren.nordrheinwestfalendirekt.de/herunterladen/der/datei/mieterstrom-2018-final-web-pdf/von/mieterstromkurz-erklaert/vom/energieagentur/2866 (accessed on 29 September 2020).

23. Jäger-Waldau, A.; Adinolfi, G.; Batlle, A.; Braun, M.; Bucher, C.; Detollenaere, A.; Frederikseng, K.; Graditib, G.; Lemush, R.; Lindahlf, J.; et al. Electricity produced from photovoltaic systems in apartment buildings and self-consumption: Comparison of the situation in various IEA PVPS countries. In Proceedings of the 2019 IEEE 46th Photovoltaic Specialists Conference (PVSC), Chicago, IL, USA, 16-21 June 2019; pp. 1701-1710. 
24. Haufe. EEG-Reform trat am 1.1.2021 in Kraft: Mieterstrom Wird Attraktiver. Available online: https://www.haufe.de/ recht/weitere-rechtsgebiete/miet-immobilienrecht/klimakabinett-fasst-beschluss-fuer-klimapaket_214_533704.html (accessed on 18 January 2021).

25. Sharma, A. Analyzing Opportunities and Barriers of Using Solar PV and Battery Energy Storage System (BESS) on Apartments or new Residential Complex. Master's Thesis, University of New South Wales Sydney, Sydney, Australia, 28 November 2019.

26. Stathopoulos, T.; Alrawashdeh, H.; Al-Quraan, A.; Blocken, B.; Dilimulati, A.; Paraschivoiu, M.; Pilay, P. Urban wind energy: Some views on potential and challenges. J. Wind. Eng. Ind. Aerodyn. 2018, 179, 146-157. [CrossRef]

27. Bundesverband Solarwirtschaft. Merkblatt EEG-Mieterstromförderung-Informationspapier des Bundesverband Solarwirtschaft. Available online: https://www.solarwirtschaft.de/fileadmin/media/pdf/BSW_Merkblatt_MieterstromG.pdf (accessed on 9 December 2019).

28. European Union. Directive (EU) 2018/2001 of the European Parliament and of the Council of 11 December 2018 on the Promotion of the Use of Energy from Renewable Sources. p. 121. Available online: https://eur-lex.europa.eu/legal-content/EN/TXT/PDF/ ?uri=OJ:L:2018:328:FULL\&from=EN (accessed on 9 February 2020).

29. Wu, X.; Zhao, S.; Shen, Y.; Madani, H.; Chen, Y. A Combined Multi-Level Perspective and Agent-Based Modeling in Low-Carbon Transition Analysis. Energies 2020, 13, 5050. [CrossRef]

30. Geels, F.W.; Schwanen, T.; Sorrell, S.; Jenkins, K.; Sovacool, B.K. Reducing energy demand through low carbon innovation: A sociotechnical transitions perspective and thirteen research debates. Energy Res. Soc. Sci. 2018, 40, 23-35. [CrossRef]

31. Geels, F.W.; Schot, J. Typology of sociotechnical transition pathways. Res. Policy 2007, 36, $399-417$.

32. Rogers, E. The Diffusion of Innovations, 5th ed.; Free Press: New York, NY, USA, 1995.

33. Mayring, P. Qualitative Inhaltsanalyse. In Handbuch Qualitative Forschung in der Psychologie; VS Verlag für Sozialwissenschaften: Wiesbaden, Germany, 2010; pp. 601-613.

34. Institut für ökologische Wirtschaftsforschung. Mieterstrom-Hindernisse und Potenziale—Kurzstudie für die Bundestagsfraktion Bündnis 90/Die Grünen. Available online: https:/ /www.ioew.de/fileadmin/user_upload/BILDER_und_Downloaddateien/ Publikationen/2017/IOEW-Studie_Mieterstrom.pdf (accessed on 19 January 2019).

35. Flieger, B.; Schachtschneider, U.; Wolter, H.; Lautermann, C.; Aretz, A.; Gährs, S.; Broekmans, J. Zukunftsfeld MieterstrommodellePotentiale von Mieterstrom in Deutschland mit einem Fokus auf Bürgerenergie. Available online: http:/ /www.transformationdes-energiesystems.de/sites/default/files/Mieterstrommodelle_Abschlussbericht.pdf (accessed on 24 January 2020).

36. Institut für Wohnen und Umwelt. Möglichkeiten der Wohnungswirtschaft zum Einstieg in die Erzeugung und Vermarktung elektrischer Energie. Available online: https:/ / www.iwu.de/fileadmin/publikationen/handlungslogiken/mieterstrom/Endbericht_ Mieterstrom.pdf (accessed on 7 November 2020).

37. Zentrum für Sonnenenergie- und Wasserstoff-Forschung. Vorbereitung und Begleitung bei der Erstellung eines Erfahrungsberichts gemäß § 97 Erneuerbare-Energien-Gesetz-Teilvorhaben II c: Solare Strahlungsenergie-Teilbericht Mieterstrom. Available online: https://www.erneuerbare-energien.de/EE/Redaktion/DE/Downloads/Berichte/vorbereitung-begleitungerfahrungsbericht-gemaess-paragraph-97-eeg.pdf?_blob=publicationFile\&v=4 (accessed on 1 February 2020).

38. Bundesverband Neue Energiewirtschaft, DGRV, EWS, Greenpeace Energy, LichtBlick, Naturstrom, Polarstern, Prosumergy, Solarimo. Diskussionspapier der Branche zur Mieterstromförderung nach EEG 2017. Available online: https://www.bne-online. de/de/news/artikel/diskussionspapier-mieterstromfoerderung/ (accessed on 7 February 2020).

39. Verbraucherzentrale Bundesverband, Bund der Energieverbraucher, GdW, Bundesverband der Energie- und Klimaschutzagenturen, bne, BSW, DGRV, Haus \& Grund, DMB, DUH, DV, Wohnen im Eigentum. Sieben Punkte-Plan für ein Besseres Mieterstromgesetz-Mieterstrom Endlich zum Durchbruch Verhelfen. Available online: https://www.vzbv.de/pressemitteilung/ energiewende-die-staedte-bringen (accessed on 28 January 2020).

40. Will, H. In neun Schritten zum Mieterstrom. Available online: https:/ /www.pv-magazine.de/2016/10/25/in-neun-schrittenzum-mieterstrom/ (accessed on 21 September 2020).

41. Immobilienwirtschaft. Mieterstrom: Der Riese schläft noch. Available online: https://zeitschriften.haufe.de/ePaper/ immobilienwirtschaft/2017/D2CB567C/files/assets/basic-html/index.html\#1 (accessed on 9 October 2020).

42. Enkhardt, S. Bundesrat beseitigt Steuerhemmnis für Photovoltaik-Mieterstrom bei Genossenschaften. Available online: https://www.pv-magazine.de/2019/06/28/bundesrat-beseitigt-steuerhemmnis-fuer-photovoltaik-mieterstrom-beigenossenschaften/ (accessed on 1 February 2020).

43. Kirchner, S. Darum bleibt der Durchbruch beim Mieterstrom aus. Available online: https://www.klimareporter.de/strom/ darum-bleibt-der-durchbruch-beim-mieterstrom-aus (accessed on 24 January 2020).

44. Wetzel, D. Mieterstrom-Die nächste Absurdität der Energiewende. Available online: https://www.welt.de/wirtschaft/article1 64078374/Mieterstrom-die-naechste-Absurditaet-der-Energiewende.html (accessed on 26 January 2020).

45. Meyer, T. Mieterstrom in der Praxis_Abwicklungsmodelle und Prozesserfahrung. Available online: https://www.bmwi.de/ Redaktion/DE/Downloads/P-R/plattform-strommarkt-ag3-10-praesentation-mieterstrom-erfahrungsbericht.html (accessed on 29 May 2020).

46. Koepp, M. Vorstellung der Studie von BH\&W und Prognos AG im Auftrag des BMWi. Available online: https://www.bmwi.de/ Redaktion/DE/Downloads/P-R/plattform-strommarkt-ag3-12-sitzung-praesentation-mieterstrom-studie-prognos-und-bhw.html (accessed on 19 February 2020). 
47. Blatter, J.; Janning, F.; Wagemann, C. Qualitative Politikanalyse. Eine Einführung. In Forschungsansätze und Methoden, 1st ed.; VS Verlag für Sozialwissenschaften: Wiesbaden, Germany, 2007. [CrossRef]

48. Witzel, A. Das problemzentrierte Interview. In Qualitative Forschung in der Psychologie, 1st ed.; Jüttemann, G., Ed.; Asanger Roland: Weinheim, Germany, 1985; pp. 227-255.

49. Bogner, A.; Littig, B.; Menz, W. Das Experteninterview: Theorie, Methode, Anwendung, 1st ed.; VS Verlag für Sozialwissenschaften: Wiesbaden, Germany, 2002. [CrossRef]

50. Köhler, J.; Laws, N.; Renz, I.; Hacke, U.; Wesche, J.; Friedrichsen, N.; Peters, A.; Niederste-Hollenberg, J. Anwendung der Mehr-Ebenen-Perspektive auf Transitionen: Initiativen in den kommunal geprägten Handlungsfeldern Energie, Wasser, Bauen \& Wohnen. Work. Pap. Sustain. Innov. 2017, 1, 1-28.

51. Bauknecht, D.; Brohmann, B.; Grießhammer, R.; Bach, M.; Funke, S. Transformationsstrategien und Models of Change für nachhaltigen gesellschaftlichen Wandel: Gesellschaftlicher Wandel als Mehrebenenansatz. Available online: https: //www.umweltbundesamt.de/sites/default/files/medien/378/publikationen/texte_66_2015_gesellschaftlicher_wandel_als_ mehrebenenansatz_3.pdf (accessed on 27 November 2020).

52. Frey, U.J.; Wassermann, S.; Deissenroth-Uhrig, M. Storage Technologies for the Electricity Transition: An Analysis of Actors, Actor Perspectives and Transition Pathways in Germany. Energies 2021, 14, 18. [CrossRef]

53. Geißler, M.; Gustedt, V. Vom Modell zur Marke—Erfahrungen der Berliner Energieagentur aus 20 Jahren Mieterstromversorgung. In Praxishandbuch Mieterstrom, 1st ed.; Behr, I., Großklos, M., Eds.; Springer Vieweg: Wiesbaden, Germany, 2017 ; pp. 143-154.

54. Sieverding, U.; Schneidewindt, H. Blockchain in der Energiewirtschaft. Available online: https://library.fes.de/pdf-files/wiso/ 12996.pdf (accessed on 2 February 2020).

55. Ministry for Economic Affairs and Energy. Stellungnahmen der Bundesländer und Verbände zum Referentenentwurf zum Gesetz zur Förderung von Mieterstrom. Available online: https://www.bmwi.de/Navigation/DE/Service/Stellungnahmen/ Mieterstrom/stellungnahmen-mieterstrom.html (accessed on 3 December 2020).

56. Bundesverband Solarwirtschaft. Mitglied werden. Available online: https://www.solarwirtschaft.de/index.php?id=120 (accessed on 3 December 2019).

57. Lichner, C. Was will der Bundesverband Neue Energiewirtschaft? Available online: https://www.pv-magazine.de/2019/09/06 /pv-magazine-audiopodcast-was-will-der-bundesverband-neue-energiewirtschaft/ (accessed on 19 November 2019).

58. VdW-Jahresstatistik 2018/2019. Available online: https://www.vdw-rw.de/fileadmin/VdW-RW/Leistungsberichte/VdWLeistungsbericht-DIN-A4-Web.pdf (accessed on 3 November 2019).

59. Rychter, A. Concluding Panel Discussion at the Event 'Nachhaltige Quartiersentwicklung: Mieterstrom und Weitere Chancen der Verbrauchernahen Energieerzeugung'; Landesverband Erneuerbare Energien NRW: Gelsenkirchen, Germany, 2019; (own transcript).

60. Bundesnetzagentur. EEG-Zubauwerte-11/2020. Available online: https://www.bundesnetzagentur.de/SharedDocs/ Downloads/DE/Sachgebiete/Energie/Unternehmen_Institutionen/ErneuerbareEnergien/ZahlenDatenInformationen/ VOeFF_Registerdaten/2020_11_EEGZubauwerte.xlsx?_blob=publicationFile\&v=2 (accessed on 12 January 2021).

61. Fraunhofer ISE. Aktuelle Fakten zur Photovoltaik in Deutschland-Fassung vom 19.12.2020. Available online: https:// www.ise.fraunhofer.de/de/veroeffentlichungen/studien/aktuelle-fakten-zur-photovoltaik-in-deutschland.html (accessed on 12 January 2021).

62. Biela, J.; Papadopoulos, Y. The empirical assessment of agency accountability: A regime approach and an application to the German Bundesnetzagentur. Int. Rev. Adm. Sci. 2014, 80, 362-381. [CrossRef]

63. Germany Federal Network Agency. Aufgaben und Struktur-Gute Infrastrukturen für die Zukunft. Available online: https:/ / www.bundesnetzagentur.de/DE/Allgemeines/DieBundesnetzagentur/UeberdieAgentur/Aufgaben/aufgaben-node.html (accessed on 9 October 2020).

64. Pantua, D. Altmaier will sich im Klimakabinett für Senkung der Strompreise Einsetzen. Available online: https:/ /www.euwidenergie.de/altmaier-will-sich-im-klimakabinett-fuer-senkung-der-strompreise-einsetzen/ (accessed on 11 October 2020).

65. Süddeutsche Zeitung. Altmaier deutet Entlastung bei Strompreisen an. Available online: https://www.sueddeutsche.de/ wirtschaft/ konjunktur-altmaier-deutet-entlastung-bei-strompreisen-an-dpa.urn-newsml-dpa-com-20090101-200527-99-20984 5 (accessed on 11 October 2020).

66. Siedenbiedel, C. Der Strompreis erreicht Rekordstand. Available online: https://www.faz.net/aktuell/finanzen/meine-finanzen/ geld-ausgeben/der-strompreis-erreicht-einen-historischen-rekord-16289878.html (accessed on 11 October 2020).

67. Eurostat 2020. Strompreisstatistik-Strompreise für Haushaltskunden, zweites Halbjahr 2019. Available online: https://ec. europa.eu/eurostat/statistics-explained/index.php?title=Electricity_price_statistics/de (accessed on 11 October 2020).

68. Lauber, V.; Jacobsson, S. The politics and economics of constructing, contesting and restricting socio-political space for renewablesThe German Renewable Energy Act. Environ. Innov. Soc. Transitions 2016, 18, 147-163. [CrossRef]

69. Dehler-Holland, J.; Schumacher, K.; Fichtner, W. Topic Modeling Uncovers Shifts in Media Framing of the German Renewable Energy Act. Patterns 2020, 100169. [CrossRef]

70. Schweiger, S.; Schecke, N.; Bönisch, A. Medial vermittelte Narrationen über die Energiewende in energieintensiven Unternehmen. Soziologie Nachhaltigkeit 2019, 5, 135-157.

71. Leiren, M.D.; Reimer, I. Historical institutionalist perspective on the shift from feed-in tariffs towards auctioning in German renewable energy policy. Energy Res. Soc. Sci. 2018, 43, 33-40. [CrossRef] 
72. Mormann, F.; Reicher, D.; Hanna, V. A tale of three markets: Comparing the Renewable energy experiences of California, Texas, and Germany. Stan. Envtl. LJ 2016, 35, 55.

73. Gawel, E.; Strunz, S. State aid dispute on Germany's support for renewables: Is the Commission on the right course? J. Eur. Environ. Plan. Law 2014, 11, 137-150. [CrossRef]

74. Von Unger, M. Germany's Renewable Energy Law, State Aid and the Internal Market: An EU Perspective. J. Eur. Environ. Plan. Law 2019, 11, 116-136. [CrossRef]

75. Kahles, M.; Pause, F. The influence of european state aid law on the design of support schemes for electricity from renewable energy sources in Germany and other member states. In The European Dimension of Germany's Energy Transition, 1st ed.; Gawel, E., Strunz, S., Lehmann, P., Purkus, A., Eds.; Springer: Berlin, Germany, 2019; pp. 67-82. [CrossRef]

76. Germany Federal Network Agency. Details zu Abgaben und Umlagen. Available online: https://www.bundesnetzagentur. de/DE/Sachgebiete/ElektrizitaetundGas/Verbraucher/PreiseRechnTarife/preiseundRechnungen-node.html (accessed on 8 November 2020).

77. Energiezukunft. Vermieter haben jetzt mehr Rechtssicherheit beim Mieterstrom. Available online: https://www.energiezukunft. eu/meinung/nachgefragt/vermieter-haben-jetzt-mehr-rechtssicherheit-beim-mieterstrom/ (accessed on 18 January 2021).

78. Baulinks. EEG 2021-Zustimmung und Kritik. Available online: https://www.baulinks.de/webplugin/2021/0020.php4 (accessed on 18 January 2021).

79. Enkhardt, S. Energiesammelgesetz Endgültig Verabschiedet-Das ändert sich 2019 für die Photovoltaik. Available online: https://www.pv-magazine.de/2018/12/14/energiesammelgesetz-endgueltig-verabschiedet-das-aendert-sich-2019-fuer-diephotovoltaik/ (accessed on 7 June 2019).

80. Handelsblatt. Große Aufgaben nach einer kleinen Reform. Available online: https://www.handelsblatt.com/inside/real_estate/ politischer-ausblick-grosse-aufgaben-nach-einer-kleinen-reform/26753608.html (accessed on 18 January 2021).

81. Rödl \& Partner. Rödl \& Partner vertritt Bürgerenergiegesellschaft im Musterverfahren zum Kundenanlagenbegriff vor dem OLG Düsseldorf. Available online: https:/ /www.roedl.de/medien/mitteilungen/roedl-partner-vertritt-buergerenergiegesellschaftmusterverfahren-kundenanlagenbegriff-olg-duesseldorf (accessed on 21 January 2020).

82. Bröer, G. Energiewende für alle möglichst preiswert machen! Solarthemen 2019, 498, 10-12.

83. Stratmann, P. PV-Potenzial erschließen. Available online: https://www.energie2020.nrw/sites/default/files/2019-05/VortragBerliner-Energietage-Stratmann-Bundesnetzagentur.pdf (accessed on 19 February 2020).

84. Lenz, C. Frühling fürs Winterpaket. Available online: https://www.pv-magazine.de/2019/04/05/fruehling-fuers-winterpaket/ (accessed on 27 August 2019).

85. Ramboll Putz \& Partner. Wechselbereitschaft von Stromkunden 2016-Bevölkerungsrepräsentative Umfrage vom 03. January 2016. Available online: https://de.ramboll.com/-/media/files/rde/management-consulting/studien_handreichungen/ ramboll_wechselbereitschaft_stromkunden_2016.pdf?la=de (accessed on 7 November 2019).

86. Michaels, L.; Parag, Y. Motivations and barriers to integrating 'prosuming' services into the future decentralized electricity grid: Findings from Israel. Energy Res. Soc. Sci. 2016, 21, 70-83. [CrossRef]

87. Statista. Urbanisierungsgrad: Anteil der Stadtbewohner an der Gesamtbevölkerung in Deutschland in den Jahren von 2000 bis 2017. Available online: https:/ / de.statista.com/statistik/daten/studie/662560/umfrage/urbanisierung-in-deutschland/ (accessed on 27 January 2020).

88. Bundesinstitut für Bau-, Stadt- und Raumforschung. Wohnungsmarktprognose 2030. Available online: https:/ /www.bbsr.bund. de/BBSR/DE/Veroeffentlichungen/AnalysenKompakt/2015/DL_07_2015.pdf (accessed on 14 February 2020).

89. Asarpota, K.; Nadin, V. Energy Strategies, the Urban Dimension, and Spatial Planning. Energies 2020, 13, 3642. [CrossRef]

90. Handelsblatt Online. Kabinett beschließt höheren Zuschuss beim Kauf von E-Autos. Available online: https://www.handelsblatt. com/politik/deutschland/verkehrswende-kabinett-beschliesst-hoeheren-zuschuss-beim-kauf-von-e-autos/25240806.html (accessed on 25 January 2020).

91. Quaschning, V. Sektorenkopplung durch die Energiewende. Available online: https://www.volker-quaschning.de/publis/ studien/sektorkopplung/Sektorkopplungsstudie.pdf (accessed on 4 February 2020).

92. Flauger, J.; Hubrik, F. Blackout-Gefahr durch Elektroautos. Available online: https:/ / www.handelsblatt.com/unternehmen/ industrie/boom-belastet-stromnetz-blackout-gefahr-durch-elektroautos/20866160.html (accessed on 28 January 2020). 